Urban, F., Zhou, Y., Nordensvard, J., Narain, A., 2015. Firm-level technology transfer and technology cooperation for wind energy between Europe, China and India: from North-South to South-North cooperation? Energy for Sustainable Development, Volume 28(10):29-40.

\title{
Firm-level technology transfer and technology cooperation for wind energy between Europe, China and India: from North-South to South-North cooperation?
}

\author{
Frauke Urban, Yuan Zhou, Johan Nordensvard, Ankita Narain
}

\begin{abstract}
:
For several decades the leading wind energy nations were European, while China and India were mainly the recipients of technology transfer. This has been challenged in recent years with the strong growth of wind energy capacity and technological capabilities in China and India. This paper aims to explore the role technology transfer and technology cooperation from Europe played in shaping leading firm-level wind energy technologies in China and India and to discuss whether the recent technology cooperation between Chinese, Indian and European wind energy firms challenges the classical North-South technology cooperation paradigm. This paper draws on fieldwork in China, India and Europe, including qualitative interviews with about 70 experts from (wind) energy firms, business associations, research organisations and government authorities. The research finds that firm-level technology transfer and cooperation shaped the leading wind energy technologies in China, such as Goldwind's permanent magnetic direct drive turbines, and to a lesser extent in India. In addition, the paper finds that several trends towards South-North technology cooperation have been observed between China, India and Europe, such as South-North flows of capital, South-North drivers for market access, South-North R\&D leadership, while the origins of innovation (e.g. patents) seem to remain predominantly in the global North. The paper concludes that the technology cooperation between China, India and Europe has become more mutual, multi-facetted and increasingly Southern-led.
\end{abstract}

Key words: Wind energy; technology transfer; technology cooperation; China; India; Europe

\section{Highlights:}

- In the past Chinese \& Indian wind technology was partly derived from EU wind firms.

- Today China and India challenge the North-South technology cooperation paradigm.

- Chinese \& Indian wind energy firms drive global flows of capital and market access.

- Chinese \& Indian wind energy firms show South-North R\&D leadership.

- Still the origins of innovation tend to remain predominantly in the global North.

\section{Introduction}


Technology transfer and technology cooperation are key mechanisms for transferring low carbon innovation ${ }^{1}$, such as wind energy technology, from high income countries to low and middle income countries. Many scholars within innovation literature have looked at innovation from a nation state perspective. Scholars such as Hu (1992), Porter, (1990) and Patel (1995) state that the national systems of innovation are important in driving forward innovation. The technology transfer and cooperation debate is still embedded in a nation state context where technology and knowledge are predominantly perceived as being passed on from developed countries to developing countries.

For at least three decades, China and India have been the recipients of transferred wind energy technology from the European Union (EU) countries (Lema and Lema, 2012; Mallet et al., 2009). This followed the classical North-South technology transfer model involving Foreign Direct Investment (FDI), Overseas Development Aid (ODA) or domestic investments for foreign-acquired technologies. The focus on the nation state and its role for technology transfer and cooperation has led to some limitations in the dominant debate. The role of firms for technology transfer has received less attention in the literature. At the same time, national innovation systems are being more and more challenged by increased globalization. Ohmae argues that the nation state has lost importance through globalization and hints at new global actors playing more important roles in diffusing innovation (Ohmae, 1990).

Wind energy markets, firms and technology have evolved over the years and firms have become increasingly important. Today, China is the world's largest wind energy market and four of its biggest wind energy firms, Goldwind, Sinovel, Guodian United Power and Mingyang, are part of the global top 10. Today, India is the world's fourth largest wind energy market and its leading wind energy firm, Suzlon, is part of the global top 10. At the same time, European wind energy markets and European technology have become internationalised due to the entry of big wind energy firms from emerging economies that have licenced technology, set up joint ventures, acquired and merged with European wind energy firms.

The theory of international technology transfer and cooperation has been discussed for at least two decades (Bell, 1990; Able-Thomas, 1996) and while climate change has increased the need and urgency for low carbon technology transfer (Hedger McKenzie et al., 2000; Brewer, 2008; Ockwell and Mallett, 2012), few fundamental changes have been witnessed in the understanding and dynamic of technology transfer. At the same time, a separate strand of literature highlights the global implications of the rise of China and India (Kaplinsky and Messner, 2008; Humphrey and Messner, 2006) and discusses how production capabilities

\footnotetext{
${ }^{1}$ Low carbon innovation is here defined as innovation of technology that has lower carbon dioxide and other greenhouse gas emissions than conventional fossil fuel technology. Wind energy technology has zero greenhouse gas emissions from its electricity generation and very low emissions from its construction, transport and waste phases, compared to fossil fuels. Wind energy technology is one of the leading low carbon technologies due to its world-wide commercial diffusion, its technological maturity and its competitive prices. Both traditional wind mills and modern wind energy turbines have been used long before climate change and the transition to a low carbon economy became public concerns. They were promoted to enable decentralised electricity production, increase energy security and help overcome peak oil. While wind energy technology is a phenomenon in itself, it could potentially provide lessons for other low carbon energy technologies, such as solar energy and hydropower technology.
} 
have been rapidly growing in these countries, while innovation capabilities are still lagging behind. Awate et al. (2012; 2014) shed light on the catch-up strategies of emerging economy multinationals and conclude this is fundamentally different to the firm strategies of advanced economy multinationals, including in the wind energy industry. This has also influenced the thinking on technology transfer and cooperation, albeit only slowly. Current literature highlights how historically Asian and European wind firms were engaged in different forms of technology transfer and technology cooperation and how Asian wind firms are increasingly catching up (e.g. Lewis, 2013; Gosens and Lu, 2013; Lema and Lema, 2013; Lema and Lema, 2012; Schmitz and Lema, 2013; Dai et al., 2014). Some literature also mentions how more recently Chinese, India and European wind energy firms are engaged in a complex set of technology cooperations (e.g. Schmitz and Lema, 2013; Lema and Lema, 2012).

The above mentioned literature is highly relevant for this paper; however it provides little discussion about how the dominant paradigm of North-South technology transfer and cooperation is challenged by the emerging economies of China and India. This paper fills a gap by examining how a new form of South-North technology cooperation for wind energy technology from China and India to the EU is changing the common understanding of technology transfer and cooperation.

The paper examines specific firm-level case studies as outlined in table 1.

Table 1: Overview of the case studies.

\begin{tabular}{|l|l|}
\hline China case study 1: Goldwind & India case study 1: Suzlon \\
\hline Vensys -Goldwind & REpower - Suzlon \\
\hline China case study 2: Other firms & India case study 2: Other firms \\
\hline Fuhrländer and Aerodyn - Sinovel, Guodian & Enercon - WindWorld India \\
United Power and Mingyang & Vensys - ReGen \\
\hline
\end{tabular}

The research questions for this paper are:

What role does technology transfer and technology cooperation from the EU play in shaping leading firm-level wind energy technologies in China and India, particularly from market leaders Goldwind and Suzlon, but also Sinovel, Guodian United Power, Mingyang, Windworld India and ReGen?

Does the recent rise of Chinese and Indian wind energy firms and their technology cooperation with European wind energy firms challenge the classical North-South technology cooperation paradigm?

Our research finds there has been a departure from the classical technology transfer and cooperation model: emerging economies being formerly at the receiving end of technology transfer and cooperation are today leaders in technology cooperation with high income countries. This has led to a new form of South-North technology cooperation, where emerging economies' capital, their firms' hunger for European markets and their flexibility to jointly adapt advanced technology for their purposes are driving the cooperation. The question around the origins of innovation, such as who develops patents and other forms of intellectual property rights (IPR), is also being challenged by Chinese and Indian wind firms. This could be seen as a form of 'reverse' technology cooperation from emerging economies in the global South, like China and India, to the global North. This has implications for the common understanding of the technology transfer and cooperation paradigm and it requires 
further investigating the sources of funding, access to markets and technology and the origins of innovation for fully understanding this new form of technology cooperation. This also means that technology cooperation between emerging economies and high income countries in the global North has become more mutual, multi-facetted and complex as the power and financial balance have shifted, while the innovative capabilities may be acquired through joint ventures and mergers and acquisitions.

Section 2 elaborates the material and methods. Section 3 presents the theoretical approach of the paper and an overview of wind energy in the EU and in China and India. Section 4 presents the empirical findings and examines issues of international technology transfer and cooperation for wind energy between the EU and China and India using the case studies. Section 5 discusses the findings and section 6 concludes the paper.

\section{Material and methods}

The paper is based on results from in-depths interviews conducted in China, India, EU (particularly Germany and Denmark) from 2011 to 2013, as well as firm strategy analysis, literature review and policy analysis.

The paper uses case studies to explore how and to what extent technology transfer and technology cooperation from the EU have shaped the leading firm-level wind energy technologies of China and India today. The case study approach is based on Yin (2009); the analytical approach used is cross-case synthesis. China, India and the EU are analysed and systematically compared as they are three large, important wind energy markets whose approach to wind energy innovation and technological development differs significantly.

The firm-level technologies we examine in this paper for China are from the firms Vensys Goldwind (DE/China), as well as from several smaller German firms such as Fuhrländer and Aerodyn that helped shape leading Chinese firm-level wind energy technologies at Sinovel, Mingyang and United Power (DE/China). The firm-level wind energy technologies we examine in this paper for India are from REpower - Suzlon (DE/India), Enercon - Windworld (DE/India) and Vensys - ReGen (DE/India).

This fieldwork involved in-depth qualitative interviews with almost 70 experts from (wind) energy firms, business associations, research organisations and government in the EU (with a focus on Germany and Denmark), China and India. The interviewees were selected based on their leading positions in their organisations and their expertise in relation to the Germany, Danish, Chinese and Indian wind energy industry. A full list of interviewed organizations can be found in the footnote ${ }^{2}$.

\footnotetext{
${ }^{2}$ Representatives from the following organisations were included in the interviews: AREVA (wind energy firm), BMU (German Ministry for the Environment), Bosch Rexroth (component supplier firm), BTM Consult (wind energy consultants), CEwind (research organisation), Danish Energy Association (business association), Danish Energy Authority (DEA, Ministry of Environment), Danish Wind Design (wind energy firm), Danish Wind Energy Association (DWIA, business association), Dong Energy (energy firm), DTU/Risø Research Centre on Renewable Energy (research organisation), Enercon (wind energy firm), Envision (wind energy firm), EWE (energy firm), ForWind (research organisation), Greenpeace (NGO), Institute for Ecological Economics Research IOEW (research organisation), LM Wind Power (wind energy firm), Mita-Teknik (component supplier firm), Norwin (wind energy firm),
} 
The interview questions were semi-structured, qualitative questions. The interviews were conducted in the local languages and then translated into English. Information which is not referenced in this paper is derived from the interviews. Additional data on the wind energy industry comes from organisations such as the Chinese Wind Energy Association, the Danish Wind Energy Association, the German Wind Energy Association, the Indian Wind Energy Association, the European Wind Energy Association EWEA, the Global Wind Energy Council GWEC and the International Energy Agency IEA.

\section{Theory}

\subsection{Conceptual framework and theory}

The paper draws mainly on the theories of international technology transfer and cooperation for low carbon innovation to explain how the transfer of low carbon technology has been fundamental in providing access to wind energy innovation in emerging economies such as China and India. The paper focuses primarily on private sector initiatives and firm-specific issues. First, the paper discusses what is meant with innovation and then technology transfer and cooperation is being discussed.

Innovation is here defined as creating something new, developing a new product, service or idea (Rogers, 2003). Technological development and innovation can follow different directions, here referred to as innovation paths. For the wind industry, the key relevant innovation actors are 1 . wind turbine manufacturers and component manufacturers; 2. research and development (R\&D) bureaus based at firms, universities and research institutes; 3. Electric utility firms that manufacture (part of) wind turbines. Other important actors are banks and credit institutions that invest in the wind industry. In the EU and India, these actors usually come from the private sector (e.g. wind turbine firms) unless they are public institutions like universities and research institutes. In China some leading wind firms and utilities are state-owned enterprises (SOEs). Urban and Nordensvard (2015) conclude

REpower (wind energy firm), Vattenfall (energy firm), VDMA Power Systems (business association), Vensys (wind energy firm), Vestas (wind energy firm), Windar Photonics (component supplier), Tsinghua University (research organisation), Bloomberg Energy (business research organisation), Chinese Ministry of Science and Technology MOST, Chinese Ministry of Environmental Protection MEP, NDRC (National Development and Reform Commission), Goldwind (wind energy firm), Sinovel (wind energy firm), Guodian United Power (wind energy firm), Mingyang (wind energy firm), Dongfang (wind energy firm), Indian Ministry of New and Renewable Energy MNRE, Indian Ministry of Power, Indian Renewable Energy Development Agency IREDA, Indian Central Electricity Authority CEA, ReGen Powertech (wind energy firm), Suzlon (wind energy firm), RRB Energy (wind energy firm), GE Energy (wind energy firm), Green Infra (energy firm), Centre for Wind Energy Technology (research organisation), World Institute of Sustainable Energy (research organisation), Bloomberg New Energy Finance (business research organisation), Prayas (NGO). Several interviewees came from the same organization, sometimes from their bases in different countries (e.g. Vestas in Denmark, Germany, India). The interviews were conducted by the authors in 2011, 2012 and 2013 at various sites in Germany, Denmark, China and India. 
that public actors and state funding play a key role for wind energy innovation in China; which differs considerably from the EU and India.

Innovation paths are defined as pathways that technological innovation follows from R\&D to commercialisation and diffusion (Dosi, 1982). Changes in innovation paths can depend on various factors like firm strategies, market strategies, competition, previous innovation (Porter, 1990). Innovation involves production capabilities and innovation capabilities. In many sectors, developed countries are leading in terms of innovation capabilities, while developing countries tend to rely more on production capabilities. However, this is changing in emerging economies. In the specific case of China and India, Altenburg et al. (2008) suggest that China and India may be transitioning from production powers to innovation powers in the long-term.

To increase access to low carbon energy technology, such as wind energy technology, in low and middle income countries such as China and India, Brewer (2007) refers to the need for a facilitation of innovation and diffusion through international technology transfer -NorthSouth, South-North and South-South- under the 'technology transfer paradigm'. The IPCC's Special Report on Methodological and Technological Issues in Technology Transfer defines 'technology transfer' as a 'broad set of processes covering the flows of know-how, experience and equipment for mitigating and adapting to climate change [...] The broad and inclusive term "transfer" encompasses diffusion of technologies and technology cooperation across and within countries. It comprises the process of learning to understand, utilise and replicate the technology, including the capacity to choose it and adapt it to local conditions and integrate it with indigenous technologies' (Hedger McKenzie et al.., 2000:1.4). This definition thus includes both technology transfer and technology cooperation. Experience has shown that the understanding of technology transfer and cooperation has broadened in recent years, moving away from pure 'hardware-thinking' to embed two distinct flows: 1 a flow of equipment as well as know-how and experience for operating, managing and maintaining the equipment from one firm or country to another, 2 a flow of technology- and business-related information from one firm or country to another such as through joint ventures and other forms of technology cooperation.

International technology cooperation refers to a wide range of cooperative approaches between firms and/or countries, including technology transfer through FDI and ODA, joint ventures, licencing agreements, mergers and acquisitions. This paper does not focus on ODA as it was more important for the early stages of the wind energy industry in China and India, such as in the 1980s and early 1990s. This paper analyses what happened in recent years with regards to technology cooperation between Europe, China and India.

International technology transfer usually requires the passing on of hardware and/or skills and experience to the recipient firm or country, often involving FDI or ODA. Joint venture refers to an internal form of technology cooperation with two or more firms working together on developing a technology. Licencing means that the technology from one firm or country is being sold and/or a licence is issued to another firm for the use of the technology. Mergers refer to the merging of two or more firms into one firm, whereas acquisitions refer to one firm buying another firm. In all of these cases hardware and sometimes software and IPR are transferred or shared with a recipient firm or country. International technology cooperation can be formal, such as through formal agreements and Memorandums of Understanding, or informal, such as through personnel movement, publications, conferences, network 
discussions (Pietrobelli, 2000) or a mixture (Ockwell and Mallett, 2013). It can also be of commercial nature, such as joint ventures and mergers and acquisitions, or it can be noncommercial, such as through development aid or scientific exchanges (Able-Thomas, 1996; Ockwell and Mallett, 2013).

The commercialised European advanced wind energy technology had its origins in the 1970 s and 1980s, with Denmark starting local manufacturing of wind turbines in the late 1970s, Germany in the early 1980s, followed by other EU countries such as Spain. India started local manufacturing of wind turbines in the mid-1990s and China in the late 1990s (Lewis, 2013). There is a history of technology transfer and cooperation, first in the form of foreign aid, later in the form of joint ventures, licencing and acquisitions between European and Chinese and Indian wind energy firms. This will be elaborated in section 4 by using case studies. Finding localised, innovative wind energy models is still a priority for climate change mitigation today (Chen et al., 2011).

'Reverse' South-North technology cooperation is here defined as technology cooperation that is driven by emerging economies in the global South, hence countries that were formerly at the receiving end of technology transfer and cooperation, but are today leaders in technology cooperation with high income countries. This involves four factors: 1 . the capital for the technology cooperation comes from emerging economies (a reverse flow of capital from South to North), potentially influencing ownership of the firm and strategic decisions; 2 . overseas market access is driven by firms from emerging economies, potentially opening up access to new markets; 3 . technologies are jointly being amended between firms from emerging economies and high income countries, potentially leading to innovative designs and technologies that are more appropriate for the new markets; 4 . the origins of innovation (such as patents and other IPRs) come from emerging economies. Amending technologies jointly (see factor 3 ) can, but must not lead to formally registering the amended technology as a patent or another form of IPR (see factor 4) and it does not indicate who/which firm holds the ownership of the IPR (see factor 4). Not all four factors of South-North technology cooperation have to be equally strongly developed. See table 2. Common forms of this type of technology cooperation are joint ventures, mergers and acquisitions. This paper questions whether 'reverse' technology cooperation has happened in wind energy technology cooperation between China, India and the EU (see the discussion in section 4). The notion of markets and suppliers has to be further unpacked: Southern markets can be supplied by (a) Northern suppliers (traditional flow of technology); (b) suppliers in their own countries (import substitution mode); or (c) suppliers from other Southern countries. Northern markets can be supplied by (a) domestic suppliers (b) suppliers from other Northern countries; or (c) suppliers from Southern countries. In the past, Northern wind energy markets have mainly been supplied by Northern suppliers, while Southern wind energy markets have to a large extent been supplied by Northern suppliers too and increasingly domestic suppliers. This research suggests that these supply strategies in Northern and Southern markets have shifted to some extent, with Chinese and Indian suppliers operating in European markets and contributing to the internationalization of global wind markets.

Table 2: Factors characterising 'reverse' South-North technology cooperation

\begin{tabular}{|l|l|}
\hline $\begin{array}{l}\text { Factors characterising 'reverse' South- } \\
\text { North technology cooperation }\end{array}$ & Description \\
\hline South-North flow of capital & The capital for the technology cooperation \\
\hline
\end{tabular}




\begin{tabular}{|l|l|}
\hline South-North drivers for market access & $\begin{array}{l}\text { comes from emerging economies (a reverse } \\
\text { flow of capital from South to North), } \\
\text { potentially influencing ownership of the firm } \\
\text { and strategic decisions. }\end{array}$ \\
\hline South-North joint R\&D / R\&D leadership & $\begin{array}{l}\text { Overseas market access is driven by firms } \\
\text { from emerging economies, potentially } \\
\text { opening up access to new markets. }\end{array}$ \\
\hline South-North origins of innovation & $\begin{array}{l}\text { Technologies are jointly being amended } \\
\text { between firms from emerging economies and } \\
\text { high income countries, potentially leading to } \\
\text { innovative designs and technologies that are } \\
\text { more appropriate for new markets. }\end{array}$ \\
\hline $\begin{array}{l}\text { The origins of innovation (such as patents } \\
\text { and other IPRs) come from emerging } \\
\text { economies. }\end{array}$ \\
\hline
\end{tabular}

Based on the conceptual framing above, the paper is based on two hypotheses:

The first hypothesis of this paper is that technology transfer and technology cooperation from the EU has contributed to shaping specific firm-level wind energy technologies in China and India. To some extent this has influenced their innovation paths.

The second hypothesis is that the recent rise of Chinese and Indian wind energy firms and their cooperation with European wind energy firms challenges the classical North-South technology cooperation model and leads to the emergence of South-North technology cooperation between Asia and the EU.

These issues will be elaborated in detail in sections 4 and 5 .

\subsection{Wind energy in the EU, China and India}

\subsubsection{Key trends and characteristics in the EU}

The EU 28 had a total installed capacity of more than 117 GW in early 2014 (GWEC, 2014). Germany currently has the largest installed wind capacity in the EU, namely about $30 \%$ of the EU's total, followed by Spain with about $20 \%$. Other leaders in wind energy in the EU are Spain, the UK, Italy, France, and Denmark (ranked according to the size of their wind markets) (GWEC, 2014; IEA, 2014). Today wind energy accounts for about 7\% of the EU's electricity consumption (GWEC, 2014).

Germany is currently Europe's largest wind energy market and the world's third largest wind energy market after China and the US with an installed capacity of more than 34 GW in early 2014 (GWEC, 2014). Germany's wind energy market has been growing continuously since the mid-1990s (BWE, 2012; IEA, 2013). The market shares of wind firms in Germany are as follows: about $60 \%$ Enercon, $20 \%$ Vestas, 10\% REpower, 4\% Nordex, $2 \%$ Bard, remaining 4\%: others, including e.n.o., Vensys, Siemens and AREVA (Lema et al., 2014; Nordensvard and Urban, 2015).

German wind energy innovation is characterised by high-quality, high-cost, large wind turbines predominantly using the Direct Drive in place of gears and mainly operating onshore, although offshore developments are increasing rapidly. In terms of deployment, the 
wind energy industry in Germany is historically located onshore, with Enercon as the stronghold of the German wind energy developers and their innovation. The offshore industry has just recently begun to grow, but is currently booming. Onshore wind technology in Germany is very advanced and has nearly reached the technical limit for energy efficiencies, according to wind energy experts.

With regard to core technology, turbine sizes rank in the multi-megawatt segment. Enercon's E-126 was the world's largest wind turbine for many years with a nameplate capacity of 7.58 MW, until Danish Vestas developed the V164 8MW turbine. Research for even larger turbines in the range of $10 \mathrm{MW}$ is currently ongoing. For offshore, wind technology still needs more development with regard to grid access and grid extension issues, installation of turbines, transport, (floating) fundaments, business models and materials (Urban and Nordensvärd, 2015; Lema et al., 2014). A key characteristic of the German wind energy technology is the Direct Drive, which has been developed by Enercon's Aloys Wobben in the early 1990s. The market leader Enercon uses an electro-magnetic Direct Drive, while Vensys uses a Permanent Magnetic Direct Drive. Other firms, such as Siemens, have also recently switched from gears to the Direct Drive (Nordensvard and Urban, 2015).

Other leading wind energy markets in the EU are Spain, home of one of the world's top wind energy firms Gamesa, as well as Denmark. Denmark has been one of the world leaders in wind turbine technology since the 1970s, thanks to its leading firm Vestas.

Denmark is the geographic home to two main wind energy firms, namely Vestas and Siemens (which is a German firm, but has its main production facilities in Denmark), as well as some component suppliers and utility firms. Danish wind energy innovation is characterised by high-quality, high-cost, large wind turbines predominantly using gears and operating both offshore and onshore, with offshore having more potential these days. With regard to core technology, turbine sizes rank in the multi-megawatt segment, with Vestas new V164 8MW offshore turbine being currently the world's largest turbine. Research for even larger turbines in the range of $10 \mathrm{MW}$ is currently ongoing. Danish wind firms, and particularly Vestas, are predominantly using turbines with gears. The gear technology has been perfected by Vestas, although it is increasingly facing competition by turbines with Direct Drives (Lema et al., 2014).

\subsubsection{Key trends and characteristics in China}

China is currently the world's largest wind energy market. None of the world's top 10 wind energy firms were Chinese a decade ago. However, after the implementation of Kyoto Protocol in 2003, Chinese wind industry experienced a quick growth both in terms of manufacturing capacity and installed capacity along with the expansion of the international wind market (Urban et al., 2012). As we will discuss in section 4, this was mainly due to technology transfer and technology cooperation with European wind energy firms.

China had an installed capacity of more than 91 GW in early 2014 (GWEA, 2014). The five largest wind energy firms are currently Goldwind (about 20\%), Sinovel (about 17\%), United Power (about 16\%), Mingyang Wind Power (about 6\%), and Dongfang (about 5\%) (Li et al., 2013). 
In terms of deployment, China adopted a large-scale wind farm strategy nationwide. More than 20 provinces have large wind energy projects under construction (Li et al., 2013).

Compared to its European counterparts, Chinese wind energy innovation is characterised by lower cost, varying quality that ranges from low to high depending on specific turbines and firms, medium to large wind turbines using both gears and Direct Drives and operating mainly onshore, although some offshore wind farms exist. Many turbines are in the medium segment of 1.5 to $2.5 \mathrm{MW}$.

In terms of core technology, China makes great technology improvements with $R \& D$ activities pushed by the government, technology imports, cooperative innovation and indigenous innovation. For example, Goldwind gained the PMDD through collaborative research and joint efforts with a joint venture with Vensys from Germany.

\subsubsection{Key trends and characteristics in India}

India is currently the fifth largest wind energy market in the world. It had an installed capacity of more than $20 \mathrm{GW}$ in early 2014 (GWEA, 2014). Wind energy technology developed in India thanks to a wind energy programme initiated by the Department for Non-Conventional Energy Sources in 1983, which was supported by funders such as the World Bank and Danish International Development Agency DANIDA.

Leading wind energy firms in India are Suzlon (about 20\%), Windworld India (about 20\%), ReGen (about 15\%) Gamesa (about 15\%), General Electric (GE) (about 15\%), and Vestas (about 10\%) (GWEA, 2014).

Compared to its European counterparts, Indian wind energy innovation is characterised by lower cost (although more expensive than Chinese turbines), varying quality that ranges from adequate to high depending on specific turbines and firms, quality, medium to large wind turbines using both gears and Direct Drives and operating onshore, with no offshore wind farms at the moment.

In terms of core technology, Indian wind turbine manufacturers are moving increasingly towards multi-megawatt turbines to be installed at greater heights. In the last half decade, the average size of wind turbine generators has increased from $767 \mathrm{~kW}$ to $1.2 \mathrm{MW}$ (Narain et al., 2014). This shift in size has led to better infrastructure and has improved the overall bankability of wind power projects by reducing the cost per unit of electricity produced. Both turbines with gears and Direct Drive exist, with gear-driven turbines being the traditional model and the Direct Drive becoming more popular due to Enercon entering India (and now being Windworld India) as well as ReGen, which is a spin-off of German firm Vensys.

\section{Results}

\subsection{Empirical findings: International technology transfer and cooperation for wind energy between the EU, China and India}

This section presents and analyses the empirical case study material (sections 4.2 and 4.3). 
This paper presents an analysis of case studies based on the type of technology cooperation between Europe and China/India. It does not focus on technological capabilities of Chinese and Indian firms as this goes beyond the scope of this paper. With regards to technological capabilities, Zhou et al. (2015) reveal a mixed picture. In recent years the number of basic patents for Chinese and Indian lead firms Goldwind, Mingyang and Suzlon has been increasing rapidly. They have now about 200-350 basic patents, which are comparable to Enercon and Siemens. Vestas is however the outlier and has far more patents. The situation is different for patent families, where Suzlon scores very high, along with Enercon and Vestas (again scoring highest), while Siemens, Goldwind and Mingyang lag behind (Zhou et al., 2015). In gerenal, Chinese and Indian lead firms lag behind regarding SCI paper publications, although Enercon has very few publications too. See table 3 for details. Zhou et al. (2015) conclude that in particular Chinese firms are weak in knowledge outflow, but demonstrate strong learning capacities (inflow), mainly based on technology cooperation as will be elaborated in this paper. Lead firm Goldwind has rapidly increased its number of patents since the acquisition of German firm Vensys. From a technological capability perspective, Indian lead firm Suzlon benefits from the acquisition of German firm REpower (Zhou et al., 2015), which again will be elaborated in the case studies below.

Table 3: Overview of technological capabilities for European, Chinese and Indian lead firms. Amended from Zhou et al., 2015.

\begin{tabular}{|l|l|l|l|l|l|l|}
\hline & Goldwind & Mingyang & Suzlon & Enercon & Vestas & Siemens \\
\hline $\begin{array}{l}\text { Patents } \\
\text { (basic, by } \\
2012)\end{array}$ & 231 & 200 & 314 & 337 & 1061 & 294 \\
\hline $\begin{array}{l}\text { Patents } \\
\text { (family, by } \\
2012)\end{array}$ & 233 & 228 & 1772 & 4826 & 5093 & 453 \\
\hline $\begin{array}{l}\text { SCl papers } \\
\text { (by 2012) }\end{array}$ & 2 & 0 & 14 & 3 & 105 & 156 \\
\hline $\begin{array}{l}\text { Ownership } \\
\text { by country }\end{array}$ & China & China & India & Germany & Denmark & Germany \\
\hline
\end{tabular}

The next sections will present the firm-level case studies for technology cooperation between Europe and China/India.

\subsection{Case study China}

The role of the Chinese wind energy industry for climate change mitigation has been analysed for some time (e.g. Lema and Ruby, 2006; Urban et al., 2012). Schmitz and Lema (2014) argue that there is a relationship between 26 Chinese turbine manufacturers and 18 (mainly) European knowledge-intensive businesses, most of which are German.

Table 4 indicates the relationship between Chinese wind energy firms and European wind energy firms with regards to different models of technology transfer and technology cooperation. Interesting to note is that the 4 top Chinese wind firms (indicated in cursive in 
the table below) have all build their wind energy expertise on technology transfer from European, mostly German, wind energy firms: Goldwind has conducted joint development with Vensys as well as licensing from Jacobs/REpower, Guodian United has licensed technology from Aerodyn, Mingyang had joint development with Aerodyn and Sinovel licensed technology from Fuhrländer.

Table 4: The relationship between Chinese and European wind energy firms with regards to different models of technology transfer and technology cooperation. Lead firms are indicated in italics. Source: Amended from Lewis, 2013.

\begin{tabular}{|l|l|l|}
\hline Chinese company & $\begin{array}{l}\text { Model of technology } \\
\text { transfer / cooperation }\end{array}$ & European source firm \\
\hline A-Power (GaoKe) & License & Fuhrländer \\
\hline & License / joint development & Norwin \\
\hline Beijing Beizhong & License & DeWind \\
\hline CSIC Haizhuang & License & Frisia \\
\hline & Joint development & Aerodyn \\
\hline DEC & License & REpower \\
\hline & Joint development & Aerodyn \\
\hline Goldwind & License & Jacobs/REpower \\
\hline & Joint venture / acquisition & Vensys \\
\hline Guodian United Power & License & Aerodyn \\
\hline Harbin Stream Turbine Co. & License & Aerodyn \\
\hline Hewind & Joint development & Aerodyn \\
\hline Huide & License & Fuhrländer \\
\hline Jiuhe & License & Windrad Engineering \\
\hline Mingyang & Joint development & Aerodyn \\
\hline REpower North & Joint venture & REpower \\
\hline Sewind & License & DeWind \\
\hline & Joint development & Aerodyn \\
\hline Sinovel & License & Fuhrländer \\
\hline Windey & License & REpower \\
\hline Xi'an Aero Engine Corp. & Joint venture & Nordex \\
\hline Xi'an - Nordex & Joint venture & Nordex \\
\hline Yinhe Avantis & Joint development & Avantis Energy \\
\hline This paper focuses specficaly on & ond case studies: & mateader Goldind and \\
\hline
\end{tabular}

This paper focuses specifically on two case studies: 1. market leader Goldwind and its relationship to Vensys, 2. other leading firms: Fuhrländer - Sinovel, Aerodyn - Guodian United Power and Mingyang. See the sections below.

\subsubsection{Technology cooperation in Europe and China: Vensys - Goldwind}

\section{Vensys}

Vensys is a German wind turbine manufacturer that was acquired by the Chinese firm Goldwind in 2008. Vensys started as a small engineering bureau that emerged from an R\&D centre at the University of Saarbrücken. Vensys has been commercially operating in Germany since 2000, whereas the R\&D activities at the university started about 10 years 
earlier. Vensys was acquired by the Chinese wind firm Goldwind with a share of $70 \%$ in 2008. Vensys operates via licensing in China (Goldwind), India (ReGen Powertech), Brazil (Enerwind/IMPSA wind) and Spain (EOZEN). It has strict rules for licensing to ensure that its intellectual property rights (IPRs) are protected. It sells its turbines in Brazil, Bulgaria, Canada, China, Germany, India, Pakistan, Poland, Portugal, Russia, Romania and the United States. Goldwind provided Vensys with access to the Chinese market and contacts; it enabled the small firm to up-scale rapidly and to supply a huge market. Goldwind has access to Vensys' profits, technology, IPRs, its components and markets. Vensys is famous for developing the Permanent Magnet Direct Drive (PMDD) which is a technology based on a permanent magnet that powers the drive, hence different from the electromagnetic Direct Drive Enercon uses. The acquisition of Vensys by Goldwind has contributed to the internationalization of EU wind markets and technology. German and Chinese technology cooperation has led to joint R\&D and joint technology. Vensys' PMDD technology requires the use of rare earths. The PMDD fits very well for production in China since China is one of the few countries that has access to rare earths resources, whereas other countries - such as Germany - struggle to access rare earths.(Urban and Nordensvärd, 2012; Lema et al., 2013). It sells medium to large turbines and is currently conducting R\&D for a $10 \mathrm{MW}$ turbine.

\section{Goldwind}

Goldwind was founded in 1998 and is headquartered in Xinjiang. As one of the earliest wind energy firms in China, it evolved in many parts of the wind energy business, including wind turbine design and manufacturing, wind resource assessment, and wind farm operation. In recent years, Goldwind has become the largest manufacturer of wind turbines in China and the 2nd largest globally (CIEDS, 2013). It has a market share of about $20 \%$ and is said to have installed a generating capacity of about 3600 MW (Li et al., 2013). With strong, internationalized R\&D capabilities, Goldwind has become the world's largest manufacturer of PMDD wind turbines. For now, Goldwind has its branches and factories located in six continents.

Goldwind experienced several key innovation paths along its development. Goldwind started the development and marketing of $600 \mathrm{kw}$ and $750 \mathrm{~kW}$ in the 1980's, leading the Chinese wind market. The early turbines installed in China relied on imported components from technology transfer. Already in 1989, the predecessor of Goldwind, China XWEC, licensed wind energy technology from German wind firm Jacobs Energie. China's first five turbines installed in 1998 had only about 33 percent local content. In 2001, Jacobs Energie merged with another company to form the REpower Systems Group. That same year, Goldwind obtained a license from REpower for a $750 \mathrm{~kW}$ turbine. In both cases, Goldwind insisted to add technician and researcher training in the contract. While Chinese engineers were sent to Germany for operational training, experts from Jacobs and REpower also went to China to work and provide on-site training. Through the immersion of design teams and experimental learning processes, Goldwind improved its innovation capacity and successfully produced turbines of $600 \mathrm{~kW}$ and $750 \mathrm{~kW}$ in 1999 and 2001, respectively. This forms the bases for later joint research of the $1.2 \mathrm{MW}$ turbine with Vensys.

In 2003, Goldwind embarked on the collaborative design of a 1.2MW PMDD wind turbines with Vensys. Unlike REpower, Vensys was a design firm who therefore was complementary to a manufacturer like Goldwind. However, Vensys only designed gearless turbine 
technology (direct drive gearless wind turbine), which was uncommon back then and is different from Goldwind's previous innovation paths -- Goldwind produced turbines with gears, namely doubly fed induction generators of $600 \mathrm{~kW}$ and $750 \mathrm{~kW}$ before. Advantages in the new innovation path meant that gearless turbines had less weight, less cost, less parts for maintenance and replacement. When considering the strategic potential, Goldwind determined to take the risk and commit to this new technology. In 2005, Goldwind had the prototype of the 1.2 MW turbine and installed it in Da Ban City wind farm for pilot operation. That became the first wind turbine produced in China over $1 \mathrm{MW}$.

Further, Goldwind also acquired the license for that $1.5 \mathrm{MW}$ turbine with a larger 64 meter diameter rotor, when integrating knowledge from Vensys to R\&D teams in China (Lewis, 2012). Based on this, Goldwind improved its magnetic electric direct-drive technology to produce 1.5MW turbines in 2007. After its acquisition of Vensys in 2008, Goldwind had already commercialized the products of the $2.5 \mathrm{MW}$ (2009) and 3.0 MW (2009) turbines, through internalizing Vensys' R\&D competences. In summarizing key factors for the success of Goldwind, former CEO Wu Gang emphasized that "insisting on collaborative research, rather than licensing technology or purchasing turbine design solutions made Goldwind strong at independent technology development" (interview, 2010). After acquiring Vensys by $70 \%$ in 2008, the registered patents for Goldwind increased from 3 in 2007 to over 170 in 2012 (Zhou et al., 2015).

Goldwind then established a joint venture with Vensys for developing 1.5MW and 2.5MW direct drive wind turbines, which made up around $20 \%$ of the total production capacity in 2012. These wind turbine models are estimated to dominate the majority of the wind market in China for the next 3 to 5 years, according to expert views. After executing its internationalization strategy, Goldwind is developing key products for the future, including wind turbines in the size of $6.0 \mathrm{MW}$ to $10 \mathrm{MW}$ for offshore use.

In addition, Goldwind and Vensys are conducting joint R\&D on amending turbines for the local conditions in China. This requires turbines that are suitable for low wind speed areas and extreme conditions such as desert conditions involving high heat, extreme dry weather and extreme sand exposure (e.g. in Gobi desert) and high altitude (e.g. for the Tibetan plateau).

Figure 1 below shows how German wind energy firms, most importantly the wind design firm Vensys, contributed to the success of Goldwind through technology cooperation.

Figure 1: Goldwind's technology cooperation with German firms Jacobs, REpower and Vensys. Amended from Lewis (2013) 


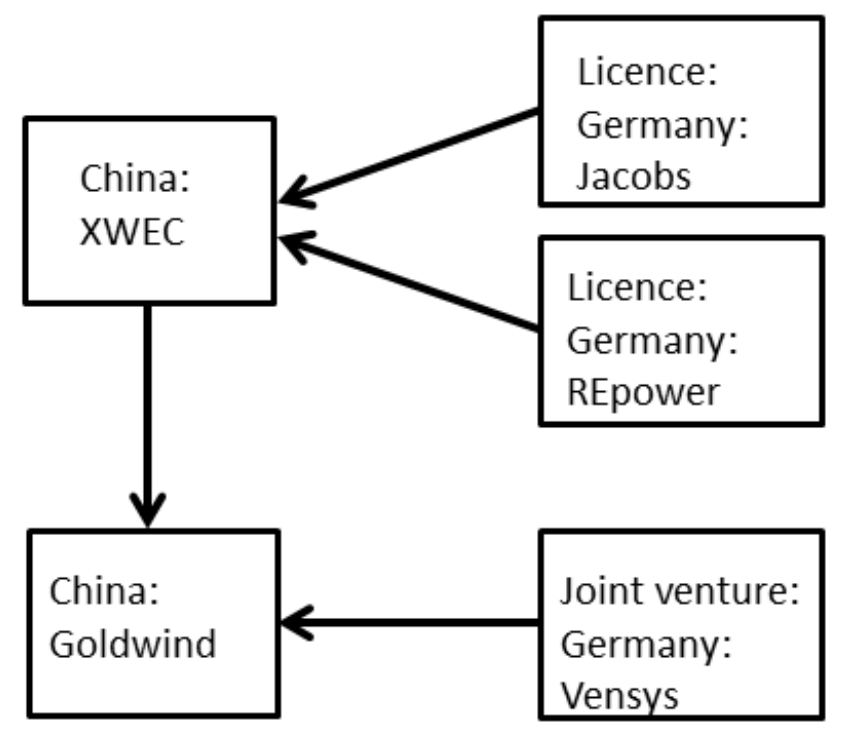

Table 5 provides an analysis how the Vensys - Goldwind technology cooperation is characterised by several factors that challenge the North-South technology cooperation paradigm.

Table 5: Factors characterising 'reverse' South-North technology cooperation: Evidence from Vensys - Goldwind

\begin{tabular}{|l|l|}
\hline $\begin{array}{l}\text { Factors characterising 'reverse' South- } \\
\text { North technology cooperation }\end{array}$ & Evidence from Vensys - Goldwind \\
\hline South-North flow of capital & $\begin{array}{l}\text { Capital flow from Goldwind to Vensys in the } \\
\text { form of a joint venture / acquisition }\end{array}$ \\
\hline South-North drivers for market access & Chinese market access driven by Goldwind \\
\hline South-North joint R\&D / R\&D leadership & $\begin{array}{l}\text { Technologies are jointly being amended by } \\
\text { Goldwind and Vensys: PMDD turbines, } \\
\text { larger turbines, amendments for extreme } \\
\text { conditions }\end{array}$ \\
\hline $\begin{array}{l}\text { South-North origins of innovation such as } \\
\text { patents and other forms of IPRs }\end{array}$ & No clear evidence found \\
\hline
\end{tabular}

\subsubsection{Technology cooperation in China: Fuhrländer, Aerodyn - Sinovel, Guodian United Power and Mingyang}

While Goldwind is China's largest wind energy firm and its most successful firm due to its advanced technology, other wind energy firms' technology also emerged thanks to technology transfer and technology cooperation with European firms, most notably German firms. Most importantly, these firms include leading firms Sinovel, Guodian United Power, Mingyang.

\section{Sinovel - Fuhrländer}

Sinovel is one of China's leading wind energy firms, currently ranking second after Goldwind, with an estimated market share of about $17 \%$ and an installed generation capacity of about 
$3000 \mathrm{MW}$ (Li et al., 2013). Sinovel was the largest wind turbine manufacturer in China since 2008 until Goldwind took the lead in 2011/12. Sinovel has had a turbulent firm history, which for years was troubled by trade disputes with the Austria-American firm AMSC (American Superconductor Corporation) over IP theft related to stolen source codes and software for upgrading Sinovel's turbines to meet Chinese grid requirements (Lewis, 2013). Sinovel also cooperated with European wind energy firm Fuhrländer, which licenced technology to Sinovel. It uses gear-driven wind energy technology, mainly in the medium-size turbine segment, originating mainly from Fuhrländer

Fuhrländer was a German wind turbine manufacturer that has been manufacturing wind turbines since the 1980s and was based in the Westerwald region of Germany. In 2012, it had to file for bankruptcy and stopped business operations in 2013. It sold gear-driven turbines in the medium-size segment. Fuhrländer sold licences to many Chinese wind energy firms, including leading wind firm Sinovel (see table 2 for details). However, unlike Vensys and Aerodyn it did not establish any joint ventures or conducted joint development with Chinese wind firms. Fuhrländer sold also licences to other countries, including to Japan and several European countries.

\section{Guodian United Power - Aerodyn}

Guodian United Power is one of China's leading wind energy firms, with a market share of about $16 \%$ and an installed generation capacity of about $2850 \mathrm{MW}$ ( $\mathrm{Li}$ et al., 2013). It belongs to one of the five big utility firms, China Guodian Corporation, that dominates the energy sector in China. It is a state-owned enterprise. It came into the wind energy sector with plenty of expertise in energy generation, transmission and distribution, but little expertise in wind energy manufacturing and wind turbine innovation. United Power therefore licenced European wind firm Aerodyn for getting access to modern wind turbine technology through technology transfer and cooperation agreements. It uses gear-driven turbines, mainly in the medium-size turbine segment, like Aerodyn.

Aerodyn is a German wind turbine manufacturer that has been operating since 1983 and is based in Rendsburg in Northern Germany. While they started operating in Germany only in the beginning, they are now selling their technology licences to the international market. Today Aerodyn's wind turbines and their components (such as rotor blades) are being sold and installed on all five continents, both onshore and offshore. It sells gear-driven turbines of up to $2.5 \mathrm{MW}$ capacity (Aerodyn, 2014). Aerodyn provides licences to China's leading wind firm United Power and is conducting joint development with Mingyang. It also has technology cooperations with at least another 5 Chinese wind energy firms - see table 1 for details.

\section{Mingyang - Aerodyn}

Mingyang is one of China's leading wind energy firms, with a market share of about $7 \%$ and an installed generation capacity of about $1200 \mathrm{MW}$ (Li et al., 2013). It has emerged in recent years and has only existed for about 8 years. It is the only non-state owned wind energy firm that is in China's top five wind manufacturers. Mingyang has joint technology development with European wind firm Aerodyn. It uses gear-driven wind energy technology, mainly in the medium-size turbine segment, like Aerodyn. 
Table 6 provides an analysis how the technology cooperation between Fuhrländer, Aerodyn - Sinovel, Guodian United Power and Mingyang is characterised by several factors that challenge the North-South technology cooperation paradigm.

Table 6: Factors characterising 'reverse' South-North technology cooperation: Evidence from Fuhrländer, Aerodyn - Sinovel, Guodian United Power and Mingyang

\begin{tabular}{|l|l|}
\hline $\begin{array}{l}\text { Factors characterising 'reverse' South- } \\
\text { North technology cooperation }\end{array}$ & $\begin{array}{l}\text { Evidence from Fuhrländer, Aerodyn - } \\
\text { Sinovel, Guodian United Power and } \\
\text { Mingyang }\end{array}$ \\
\hline South-North flow of capital & $\begin{array}{l}\text { Capital flow from Chinese firms to European } \\
\text { firms in the form of licencing and joint } \\
\text { development }\end{array}$ \\
\hline South-North drivers for market access & Moderate market access to China \\
\hline South-North joint R\&D / R\&D leadership & $\begin{array}{l}\text { Technologies are jointly being amended by } \\
\text { Mingyang and Aerodyn: gear-driven turbines, } \\
\text { multi-megawatt turbines }\end{array}$ \\
\hline $\begin{array}{l}\text { South-North origins of innovation such as } \\
\text { patents and other forms of IPRs }\end{array}$ & No clear evidence found \\
\hline
\end{tabular}

As this analysis shows the four leading Chinese wind energy firms rely on technology acquired through various forms of technology transfer and technology cooperation from European, wind firms, mostly from Germany. Most common technology cooperation mechanisms are licensing and joint ventures. The access to these Sino-European technology cooperations without doubt contributed significantly to the emergence of the Chinese wind energy technology and industry.

\subsection{Case study India}

Table 7 indicates the relationship between Indian wind energy firms and European wind energy firms with regards to different models of technology transfer and technology cooperation. In comparison to the Chinese case, Indian wind firms such as Suzlon have relied more on mergers and acquisitions, purchasing $R \& D$ departments and developing joint ventures rather than going down the licencing route. This meant more innovation originated from India and a reliance on licencing foreign technology was lower than for China.

Table 7: The relationship between Indian and European wind energy firms with regards to different models of technology transfer and technology cooperation.

\begin{tabular}{|l|l|l|}
\hline Indian company & $\begin{array}{l}\text { Model of technology } \\
\text { transfer / cooperation }\end{array}$ & European source firm \\
\hline Suzlon & License & Südwind \\
\hline Suzlon & Acquisition & Südwind R\&D \\
\hline Suzlon & Joint Venture & AE Rotor Techniek Company \\
\hline Suzlon & Acquisition & REpower \\
\hline ReGen PowerTech & License & Vensys \\
\hline RRB & Joint Venture & Vestas \\
\hline Enercon India (Later & Joint Venture / Subsidiary & Enercon \\
\hline
\end{tabular}




\begin{tabular}{|l|l|l|}
\hline WindWorld India) & & \\
\hline Pioneer & Joint Venture & Gamesa \\
\hline
\end{tabular}

This paper focuses specifically on two case studies: 1. market leader Suzlon and its relationship to REpower, 2. other leading firms: Enercon - WindWorld India, Vensys ReGen.

\subsubsection{Technology cooperation in Europe: REpower - Suzlon}

\section{Suzlon}

Indian market leader Suzlon was founded in 1995, diversifying from a family-run textile business. Its owners and managers, Tanti family, gained valuable experience about wind energy technology whilst installing two wind turbines to power their textile business. Suzlon entered the Indian wind energy sector by selling turbines manufactured by its licensor, German wind energy firm Südwind. In 1997, Südwind filed for bankruptcy. Suzlon took this opportunity to build its own technical and manufacturing capabilities by acquiring parts of Südwind's R\&D division and hiring its employees. Suzlon thus set up its own R\&D facilities in Rostock, Germany (Narain et al., 2014).

Since 1997-98, Suzlon has been manufacturing and developing new wind turbines for the Indian market. In 2001, Suzlon established a rotor blades research facility in the Netherlands with $\mathrm{AE}$ Rotor Techniek Company along with forming strategic alliances with Dutch researchers and collaborations with Enron Wind Rotor Production and Aerpac B.V. From 2002-2005 Suzlon set up research and representative offices in the USA, China and Germany, expanding both their research endeavours and target markets. Suzlon's core business model was the full vertical integration of all wind-related activities, as figure 3 indicates.Thus, to reduce cost of production and improve their competitiveness in the international market, Suzlon acquired new resources to achieve full integration of the wind technology services. This gave Suzlon the advantage to not only manufacture wind towers, but also use expertise from different countries for various parts of the wind turbine value chain - aerodynamic parts from the Netherlands, generators from Austria, turbines from Germany, and information and software technology from India (Narain et al., 2014).

Hence, through technology transfer licensing and developing subsidiaries across the globe, Suzlon established itself as leading company in wind energy technology solutions. By 2009 , Suzlon had installed 4,400 MW of wind energy capacity in eight states across India. It is estimated that over the period of 2004-2009, Suzlon's cumulative installed base grew by $400 \%$. Globally Suzlon has reported having an installed over 15,000 MW of wind energy (Narain et al., 2014).

Suzlon acquired German wind energy firm REpower in 2007 to gain access to the German market. This has contributed to the internationalization of the German wind energy market, with Indian firms (as well as Chinese) entering the market via acquisitions and mergers and contributing to its strategic and technological development.

Figure 2 shows how European wind energy firms contributed to the establishment of Suzlon through technology cooperation. The figure also shows how Suzlon purchased German wind firms, including REpower which did not contribute to the establishment of Suzlon or its technology, but opened the doors for the European wind market (hence the inverted arrow). 
Figure 2: Suzlon's technology cooperation with European firms and its take-over of REpower.
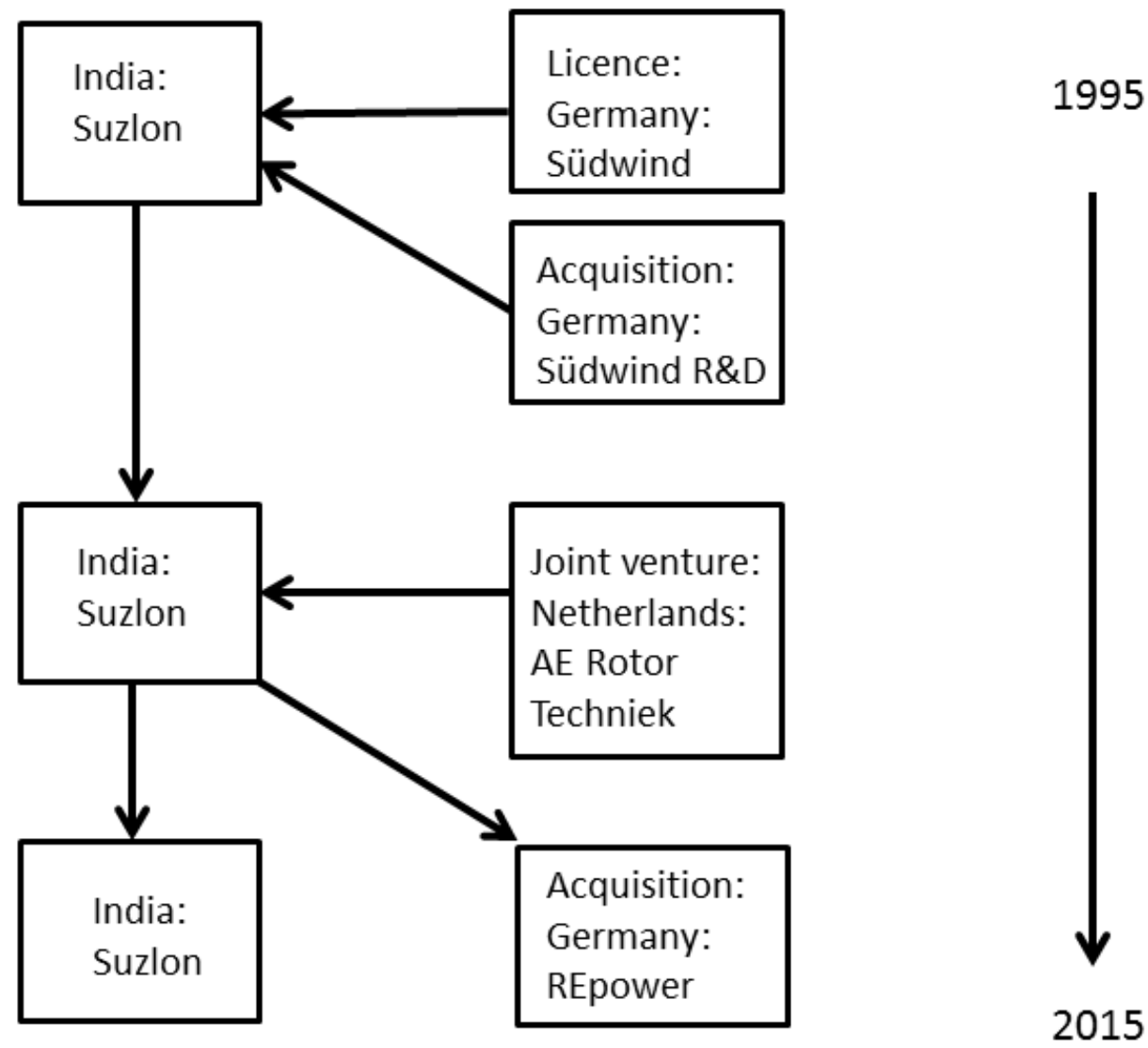

Figure 3 shows Suzlon's international business model.

Figure 3: Suzlon's business model. Source: Narain et al., 2014. 


\section{The Suzlon Model}

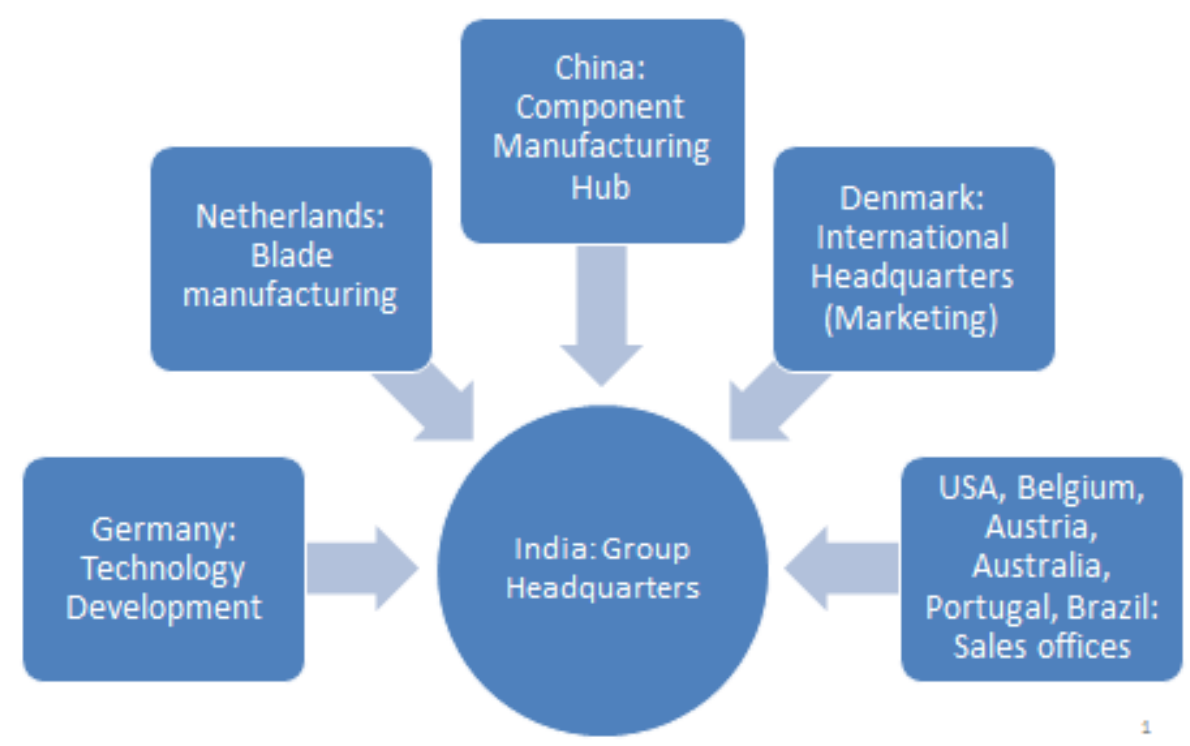

\section{REpower}

REpower started as a German small and medium enterprise (SME) and has been active in the wind energy industry since 1980 through its predecessor. REpower in its present form exists since 2001. REpower focuses both on onshore and offshore wind energy. REpower's $6 \mathrm{MW}$ offshore was until 2014 the largest offshore turbine in the world, it was then overtaken by Vestas $8 \mathrm{MW}$ turbine. Its business model is characterised by being a quality turbine producer, which has powerful turbines and emphasises reliability of turbines, service and maintenance. REpower operates turbines with gears. Most of its components come from suppliers, however REpower develops its own rotor blades. The company has German suppliers (e.g. Siemens), European suppliers and Asian suppliers, which it intends to expand in the future. Since 2007, the Indian wind firm Suzlon has taken over $100 \%$ of REpower, this process was fully finalised in late 2012. Nevertheless REpower is independent as there is no profit transfer; Suzlon does not have access to REpower's technology nor its IPRs, but Suzlon has access to some of REpower's components and access to the German market (Urban and Nordensvärd, 2012; Lema et al., 2013).

Table 8 provides an analysis how the REpower - Suzlon technology cooperation is characterised by several factors that challenge the North-South technology cooperation paradigm.

Table 8: Factors characterising 'reverse' South-North technology cooperation: Evidence from REpower - Suzlon

\begin{tabular}{|l|l|}
\hline $\begin{array}{l}\text { Factors characterising 'reverse' South- } \\
\text { North technology cooperation }\end{array}$ & Evidence from REpower - Suzlon \\
\hline South-North flow of capital & $\begin{array}{l}\text { Capital flow from Suzlon to REpower in the } \\
\text { form of an acquisition }\end{array}$ \\
\hline South-North drivers for market access & $\begin{array}{l}\text { European market access driven by Suzlon } \\
\text { through REpower }\end{array}$ \\
\hline South-North joint R\&D / R\&D leadership & No clear joint R\&D strategies reported, \\
\hline
\end{tabular}




\begin{tabular}{|l|l|}
\hline such as jointly amending technologies & $\begin{array}{l}\text { although Suzlon had joint R\&D with other } \\
\text { European firms before its acquisition of } \\
\text { REpower }\end{array}$ \\
\hline $\begin{array}{l}\text { South-North origins of innovation such as } \\
\text { patents and other forms of IPRs }\end{array}$ & No clear evidence found \\
\hline
\end{tabular}

\subsubsection{Technology cooperation in India: Enercon - Wind World India, Vensys - ReGen and others}

\section{Enercon - Wind World India}

Enercon is a German wind turbine manufacturing firm founded in 1984. Enercon began with manufacturing small gearbox turbines, but shifted to gearless turbines in 1992. Enercon today has installed over 18,000 turbines worldwide. Enercon is Germany's most important and most established wind energy firm, which has a market share of over $60 \%$ and has been operating for over 25 years. The firm is well known for being the innovator that developed the Direct Drive, a gearless technology. The advantage of the Direct Drive is that it is more efficient and has better reliability over the entire lifetime of a wind turbine compared to gears, but the service and maintenance is more complicated compared to gears. The disadvantages are its higher costs in comparison to gear-driven turbines. Enercon uses an electromagnetic Direct Drive. The company is the most prolific member of the Germany wind energy industry; it is also largely shaped by its charismatic founder Aloys Wobben. Some describe Enercon as a "hidden champion" since it offers an "innovative product, exceptional service, strong internationalization and, as a result, a high rate of growth" (Orth, 2008:12). The innovation of Enercon is based both on its innovation in wind energy technology and its innovative and very specialised business model (Urban and Nordensvärd, 2012).

Enercon entered the Indian wind energy market in 1994 by establishing a subsidiary company in India. Enercon has had some success in India over the past decade and half with wind farms in seven high wind potential states - Karnataka, Maharashtra, Tamil Nadu, Rajasthan, Gujarat, Madhya Pradesh and Andhra Pradesh. In total, Enercon India has installed 2,900 MW of wind energy in India.

Enercon's endeavor to prosper on the Indian market has been problematic in the long-run. Its business in India has been in a decline in recent years. "The Indian subsidiary of the German firm Enercon has lost a significant market share over the last few years (2003: 24\%, 2008: less than 8.5\%)" (Walz and Delgado, 2012:101). In March 2011, the German parent company, Enercon Gmbh reported a dispute with its local Indian partner due to intellectual property rights (IPR) infringements and licensing problems. There are claims that the Indian subsidiary and its patents have been lost. In 2013, the minority owners, Enercon India, rebranded the local joint venture as Wind World India Ltd. and continue to operate under this name with Enercon's technology.

\section{ReGen - Vensys}

ReGen Powertech entered the Indian market in 2006 and has become one of the fastest growing companies in a slow-growth economy. Currently it has the third largest share of the 
Indian market and the largest share in the independent power provider market. Its key offering to the market is a gear-less 1.5 MW PMDD turbine. It has a technology cooperation through licencing with Vensys, Germany, almost making it the Indian arm of the Chinese manufacturer, Goldwind (Goldwind acquired Vensys in 2008) (Narain et al., 2014). It uses wind turbines designed for low wind speed areas based on licencing technology from German firm Vensys.

ReGen Powertech has thus far installed near $400 \mathrm{MW}$ of wind energy in India, primarily for corporate customers including steel companies, textile manufacturers and mills and developers such as India Energy and Tata Power. As the Indian policies moves to support quality of turbines over installations (via generation based incentives), ReGen hopes to gain more market share as they argue the Direct Drive turbine is a better long term investment with decreased maintenance requirements.

\section{RRB - Vestas}

Starting as an acquisition of Danish wind firm Vestas, RRB Energy Limited manufactures and supplies wind turbines for harnessing power from wind in India. It produces blades and microprocessor based on wind turbine controllers. The company also operates as an independent power producer of wind power. In addition, it offers solutions in the area of harnessing wind energy for power generation, which include site selection, micrositing, preparation of detailed project report, project engineering erection, commissioning, and after sales service of wind power projects. The company was formerly known as Vestas RRB India Limited and changed its name to RRB Energy Limited in January 2008 after further acquisitions. The company was incorporated in 1987 and is based in Chennai, India. RRB Energy Limited operates as a subsidiary of Eco RRB Infra Private Limited (Narain et al., 2014).

As this analysis shows some Indian wind energy firms rely on technology transfer and technology cooperation with European wind firms, mostly joint ventures and some licencing. However, India's market leader Suzlon relied much more on its own innovations and on mergers and acquisitions than its Chinese counterparts.

Table 9 provides an analysis how the technology cooperation between Enercon - Wind World India, Vensys - ReGen and others is characterised by several factors that challenge the North-South technology cooperation paradigm.

Table 9: Factors characterising 'reverse' South-North technology cooperation: Evidence from Enercon -Wind World India, Vensys - ReGen and others

\begin{tabular}{|l|l|}
\hline $\begin{array}{l}\text { Factors characterising 'reverse' South- } \\
\text { North technology cooperation }\end{array}$ & $\begin{array}{l}\text { Evidence from Enercon - Wind World } \\
\text { India, Vensys - ReGen and others }\end{array}$ \\
\hline South-North flow of capital & $\begin{array}{l}\text { Capital flow from Indian firms to European } \\
\text { firms in the form of licencing and joint } \\
\text { ventures, although for Enercon a North- } \\
\text { South flow of capital has been observed }\end{array}$ \\
\hline South-North drivers for market access & Moderate market access to India \\
\hline South-North joint R\&D / R\&D leadership & $\begin{array}{l}\text { Technologies are jointly being amended by } \\
\text { ReGen and Vensys: PMDD turbines; RRB } \\
\text { and Vestas: gear-driven turbines; Pioneer } \\
\text { and Gamesa: gear-driven turbines; }\end{array}$ \\
\hline
\end{tabular}




\begin{tabular}{|l|l|}
\hline & $\begin{array}{l}\text { Enercon's Indian subsidiary Wind World is } \\
\text { now developing its own technology based on } \\
\text { Enercon's direct drive technology }\end{array}$ \\
\hline $\begin{array}{l}\text { South-North origins of innovation such as } \\
\text { patents and other forms of IPRs }\end{array}$ & No clear evidence found \\
\hline
\end{tabular}

\section{Discussion}

\subsection{The implications for national innovation paths and the internationalization of wind markets and technologies}

The analysis above revealed that the technology of leading wind energy firms in China and India, such as Goldwind, Sinovel, Mingyan, United Power as well as Suzlon, Windworld India and ReGen is linked to international technology cooperation with European wind firms in one way or the other. This has traditionally been the case with regards to technology transfer, particularly in China, while more recent technology cooperations include joint ventures and acquisitions. It is striking that German firms are particularly strongly engaged in technology cooperation with Asian wind firms. This has two main implications:

First, Asian innovation paths in wind energy, particularly in China, have to some extent evolved based on the technology they acquired from their European technology cooperation partners. Wind energy technology from Europe has therefore helped shape Chinese wind energy technology and innovation paths and more recently also partly India's wind energy technology. Goldwind's wind energy technology is characterised by the gear-less PMDD and the up-scaling of turbines which originated from Vensys and which are now being developed as joint cooperations. Windworld India operates with advanced Direct Drive technology from Enercon, ReGen does the same with licences from Vensys. At the same time Sinovel's technology depended on licensing from Fuhrländer, United Power's technology depended on licencing from Aerodyn and Mingyang's technology depended on joint development with Aerodyn. The striking outlier is Suzlon. In its beginnings, Suzlon aimed to develop technology domestically, partly through the Südwind license from Germany. However, its rise as market leader was because of its various acquisitions across leading wind energy firms and actors. By following the acquisition model, it not only gained technology and expertise, but also access to bigger and more advanced markets. Today Suzlon is a global business that operates world-wide, in emerging markets as well as in established markets such as North America. Suzlon acquired German wind energy firm REpower not because it needed access to advanced technology, but because it needed a reliable, reputable European brand for access to the European market. As such the acquisition of REpower by Suzlon is fundamentally different to the acquisition of Vensys by Goldwind. Unlike with Vensys-Goldwind, Suzlon does not have access to REpower's full technology nor its IPRs, but Suzlon has access to some of REpower's components and access to the German market in which it operates as the European brand REpower. These findings suggests that the supply strategies in Northern and Southern markets have shifted to some extent, with Indian and Chinese suppliers opening up wind energy markets in Europe and contributing to the internationalization of global wind markets.

Secondly, the entry of Asian wind energy firms into European markets as well as the entry of European wind technology in Asian markets has led to an internationalization of global wind 
energy markets and technologies. Our interviews reveal that large Asian wind energy firms such as Goldwind offer opportunities for profits, employment and economic growth for smaller wind design firms such as Vensys. Thanks to Goldwind, Vensys now has access to the world's largest wind energy market in comparison to before operating at very limited scales without long-term profitability and strong business partners. Suzlon's acquisition of REpower has further contributed to the internationalization of the European wind energy market. These new technology cooperations between Asia and Europe contribute to making wind energy markets and technologies global rather than national or regional and further breaking down the boundaries between markets and national/firm-level technologies. This has implications for the nature of international technology cooperation as we will discuss below.

\subsection{The implications for the nature of international technology cooperation: from North-South technology transfer to South-North technology cooperation?}

Different types of international technology cooperation, such as technology transfer through FDI and ODA, licencing, joint ventures, mergers and acquisitions are an important strategy for developing the wind energy industry as a late-comer.

Going back to the conceptual framework, we conclude the following: 1. Our research found that the capital for the technology cooperation has in some cases come from China (Goldwind) and India (Suzlon) to the benefit of European firms, thereby influencing ownership of the firm and strategic decisions related to $R \& D$, technology choices, market access, investments, employments etc (Vensys and REpower). 2. Our research concluded that overseas market access for European wind firms is driven by wind firms from China, thereby opening up access to the huge Chinese market (e.g. Vensys-Goldwind). The same did not apply to India as wind technologies in Europe and India are being marketed as separate brands (e.g. Suzlon-REpower). 3. We also found that technologies are jointly being amended between firms from emerging economies and high income countries, potentially leading to innovative designs and technologies that are more appropriate for new markets such as low-wind speed turbines, high altitude and desert condition turbines etc (VensysGoldwind, to some extent Indian and other Chinese firms); 4. Our research found little evidence that suggests that the origins of innovation, such as patents, come increasingly from emerging economies in technology cooperation deals between the EU and emerging economies. Patent data analysis reveals a mixed picture indicating that China and India are slowly catching up though (Zhou et al, 2015). In line with these findings, our research found that joint R\&D, particularly for amended technologies, happens between Chinese, Indian and European firms, but the ownership of the IPRs seems to be predominantly resting with European firms. This requires close observation and future research over the coming years and decades when this balance might change.

We found that there are distinct differences between China and India with regards to the wind energy industry. India has a very successful domestic wind energy industry driven by the domestic efforts of Suzlon, which only acquired parts of foreign firms, such as R\&D departments. It is only very recently that EU firms such as REpower, Enercon and Vensys began making a more significant contribution to India's technology and innovation paths. China on the other hand has mainly relied on technology transfer in the early beginning of its 
wind energy sector. More recently it has gained access to advanced wind energy technology through joint ventures, the acquisition of entire foreign firms and the licencing of foreign technology. Fast technological catch up has therefore happened in the case of China which has speeded through the early stages of the technological development of wind energy technology. Today, China uses advanced wind energy innovation, such as the permanent magnetic Direct Drive and multi-megawatt turbines, including for the offshore market. This has not happened until recently in India due to its long-standing domestic industry which is based to a large extent on Suzlon's Indian-based experiences.

The implication of China's and India's catch up is that these two countries are the new global leaders in wind energy, in terms of market shares and investments, while they are slowly catching up in terms of innovation capabilities. Goldwind (as well as other Chinese firms) and Suzlon are today key rivals to the old established EU players like Vestas and Enercon. This opens up opportunities for cooperation between the EU and emerging economies, such as the acquisition of Vensys by Goldwind and REpower by Suzlon. However it also leads to challenges and concerns in relation to competition such as the ability of Chinese turbine manufacturers to compete in European markets with European-based technology at lower costs. Fuhrländer's bankruptcy shows that in an increasingly competitive and internationalised market, licencing wind energy technology may not be sufficiently profitable, while joint ventures and acquisitions may offer more stable financial futures in some cases (see e.g. Vensys - Goldwind and REpower -Suzlon). This also means that the 'new' Asian leaders in wind energy contribute to the internationalization of EU wind energy markets and technology, for example by acquisitions. In addition, this means that Asian wind firms tend to bring new capital to financially less stable European wind firms, whereas the innovation capabilities remain largely with the European counterparts. This new form of South-North technology cooperation could distort the decade-long power balance between Europe and Asia in the wind energy sector.

As three of the four factors that characterise South-North technology cooperation have been observed we see an emerging pattern that may challenge the dominance of the classical North-South technology cooperation paradigm in the long-term. It is no longer the global North that solely dominates global wind energy markets through flows of capital, drivers for market access and R\&D leadership. As the tables begin to turn it is increasingly the global South that dominates global wind energy markets through flows of capital, drivers for market access and R\&D leadership. It is the Asian wind energy firms today that turn towards European wind energy firms to invest in joint ventures and to acquire entire wind energy firms. Faced with the global financial crisis, increasing unemployment and threats of bankruptcy among renewable energy firms (e.g. wind energy firm Fuhrländer and many solar energy firms), many European wind energy firms cannot turn away the offer of technology cooperation from their Asian counterparts. The power constellations and the financial potency of Europe versus Asia have begun to shift in the global wind energy market.

\section{Conclusion}

This paper explored how technology transfer and technology cooperation from the EU shaped specific firm-level wind energy technologies that influenced the national innovation 
paths in China and India. The paper also discussed how the cooperation between China, India and the EU evolved over time moving from technology transfer from European firms to Asian firms to newer forms of technology cooperation. This research concludes that in the past, technology transfer and technology cooperation from the EU played a major role in influencing the design and direction of leading firm-level wind energy technologies in China (Goldwind, Sinovel, Guodian United Power, Mingyang), and more recently also India (Windworld India and ReGen). While this paper mentioned technological capabilities on the margins, the main focus of the paper was to analyse how different types of technology cooperation between the EU and China/India, such as licencing, joint ventures, mergers and acquisitions, led to the development of specific firm-level wind energy technologies by Chinese and Indian lead firms. The cutting-edge wind energy technologies we currently see in China and India are similar to those of lead firms in Europe, for example multi-megawatt turbines for on- and offshore use and turbines with Direct Drive. This echoes the cuttingedge technology of firms such as Vensys and Enercon. In China we also see gear-based wind technology that is derived from licenced technology from Fuhrländer and Aerodyn. To link this back to the innovation literature of $\mathrm{Hu}$ (1992), Porter (1990), Patel (1995) and Ohmae, these findings challenge the common understanding of national systems of innovation as wind firms and markets become increasingly globalized and internationalized.

The paper further discussed different strategies that China and India used for achieving fast technological catch up in the wind energy sector. China has historically depended on technology transfer to build up its wind energy industry, whereas India has developed more independently thanks to strong local innovation at Suzlon, although in recent years foreign licenses from Enercon and Vensys have been of importance. More recently, other forms of technology cooperation, such as joint ventures and mergers and acquisitions play a role for fast technological catch up for China, and increasingly also for India. Nevertheless recently it was important for India's leading firm Suzlon to acquire European firm REpower for access to European markets, rather than for access to their technology.

This research found that three of the four factors that characterise South-North technology cooperation have been observed (South-North flows of capital, South-North drivers for market access, South-North joint R\&D / R\&D leadership, while South-North origins of innovation has been less observed). Zhou et al.'s (2015) patent analysis shows a mixed picture with indications that patents and SCl publications from leading Chinese and Indian wind firms are increasingly occurring, although still at a lower level compared to leading European wind firms (Zhou et al., 2015). Hence we see an emerging pattern that may challenge the dominance of the classical North-South technology cooperation paradigm in the long-term. While it is too early to speak of reverse technology cooperation, South-North technology cooperation between China, India and Europe may become a common practice amongst wind energy technology firms in the long-term. The move away from Asian firms being recipients of wind energy technology to more mature forms of technology cooperation (such as mergers and acquisitions and joint ventures) challenges the classical North-South technology cooperation paradigm and indicates complex forms of South-North technology cooperation. This also means that technology cooperation between emerging economies and high income countries in the global North has become more mutual and multi-facetted as the power and financial balances have shifted, while the innovative capabilities may be acquired through joint ventures and mergers and acquisitions. 
A new strategy of becoming a global leader in wind energy technology has been proven, particularly by China. For the global low carbon economy this means that the strategy of South-North technology cooperation in the wind sector could be replicated by other emerging economies, such as Brazil which has international technology cooperation with Enercon and Vensys. Further research in this field is needed.

This new knowledge adds to the body of literature on international technology transfer and technology cooperation. The paper looked beyond the classical North-South technology transfer paradigm and studied newly emerging forms of technology transfer and cooperation from the global South to the global North by using wind energy technology in China, India and the EU as case studies.

Acknowledgements: This project has been funded by the Svenska Riksbankens Jubileumsfond, the Volkswagen Foundation and the Compangnia di Sao Paolo as part of the 'Technological trajectories for climate change mitigation in Europe, China and India project'. We are grateful to all the interview respondents who participated in the fieldwork. We would like to thank Rasmus Lema for some information on wind energy in Denmark. Many thanks to Daniel. B Jones and Gautam Dutt for useful comments on an earlier version of the paper. Thanks to other colleagues who have been providing comments on draft versions of the paper.

\section{References}

Able-Thomas, U., 1996; Models of Renewable Energy Technology Transfer to Developing Countries. In Renewable Energy, Energy Efficiency and the Environment. AA. Sayigh, (ed.), Pergamon Press, New York, pp. 1104-7.

Aerodyn, 2014. Company profile. http://www.aerodyn.de/

Altenburg, T.; Schmitz, H. and Stamm, A. (2008) ,Breakthrough? China's and India's Transition from Production to Innovation', World Development 36.2: 325-34

Awate, S., Larsen, M.M., and Mudambi, R. 2014. Accessing vs sourcing knowledge: A comparative study of $R \& D$ internationalization between emerging and advanced economy firms. Journal of International Business Studies.

Awate, S., Larsen M, Mudambi R., 2012. EMNE catch up strategies in the wind turbine industry: Is there a trade-off between output and innovation capabilities?, Global Strategy Journal , 2 (3), 205-223

Barton, J. H., 2007. Intellectual Property and Access to Clean Energy Technologies in Developing Countries. ICTSD Trade and Sustainable Energy Series, Issue Paper No. 2. Geneva, Switzerland, ICTSD.

BMU Bundesministerium für Umwelt, Naturschutz, Bau und Reaktorsicherheit, 2011. Hintergrundinformationen zum Ausbau der Erneuerbaren Energien in Deutschland bis 2020; online: http://www.bmu.de/files/pdfs/allgemein/application/pdf/hintergrund ausbau ee bf.pdf 
BMU, 2012. Details about the renewable energy law (EEG) and the feed-in tariff; online: http://www.bmu.de/files/pdfs/allgemein/application/pdf/eeg 2012 verguetungsdegression bf .pdf

Brewer, T.L., 2007. Technology, Emissions Trading and International Trade. New Issues and Paradigms for the Expanding Climate Change Agenda. Annual Meeting of the Swedish Network of European Economists, Mölle.

BWE German Wind Energy Association, 2012. German Wind Energy Report. BWE, Berlin.

Chen, L., Ponta, F.L., Lago, 2011. Perspectives on innovative concepts in wind-power generation. Energy for Sustainable Development, Vol. 15(4): 398-410.

CIEDS China Institute of Engineering Development Strategy, 2013). Report on the development of China's Strategic Emerging Industries 2013. Science Press, Beijing.

Dai, Y.X., D., X., Ding, M.Y., Lan, X., 2014. The innovation paths of the Chinese Wind Power Industry. GDI working paper. GDI, Bonn.

Dosi, G. (1982): Technological paradigms and technological trajectories: a suggested interpretation of the determinants and directions of technical change, in: Research Policy 11 (3), 147-162

Forsyth, T., 1999. International investment and climate change: energy technologies for developing countries. Earthscan, London.

Gosens, J. and Lu, Y.L., 2013. From Lagging to Leading? Technologies Innovation Systems in Economies and the Case of Chinese Wind Power, Energy Policy, Vol.60(3):234-250.

GWEC Global Wind Energy Council, 2014. Global Wind Report 2013. http://www.iea.org/statistics/

Hedger, McKenzie M.; Martinot, Eric; Tongroj Onchan, 2000. "Enabling Environments for Technology Transfer". In, Methodological and Technological Issues in Technology Transfer, eds. Bert Metz, Ogunlade R. Davidson, Jan-Willem Martens, Sascha N.M. van Rooijen and Humphrey, J. and Messner, D. (2006) 'China and India as Emerging Global Governance Actors: Challenges for Developing and Developed Countries', IDS Bulletin, Vol.37(1):107114.

Hu, Y. S. 1992. Global or transnational corporations are national firms with international operations. Californian Management Review

Kaplinsky, R. and Messner, D. (2008) 'Introduction: The impact of Asian drivers on the developing world', World Development, Vol. 36(2): 197-209

Laura Van Wie McGrory. Intergovernmental Panel on Climate Change IPCC. Cambridge University Press: Cambridge pp 105-141.

IEA International Energy Agency, 2014. Energy Statistics. http://www.iea.org/statistics/

Lema, R.; Berger, A. and Schmitz, H. (2013) ,China's Impact on the Global Wind Power Industry', Journal of Current Chinese Affairs 1/2013: 37-69 
Lema, R., Nordensvärd, J., Urban, F., Lutkenhorst, W., 2014. Technological Trajectories for Climate Change Mitigation in Europe, China and India. Wind Energy in Europe. GDI Working Paper. GDI, Bonn.

Lema, R. and Lema, A., 2013. Technology transfer in the clean development mechanism: Insights from wind power. Global Environmental Change, Vol.23(1):301-313.

Lema, R. and Lema, A., 2012. Technology transfer? The rise of China and India in green technology sectors. Innovation and Development, Vol.2(1):23-44.

Lema, A. and Ruby, K., 2006. Towards a policy model for climate change mitigation: China's experience with wind power development and lessons for developing countries. Energy for Sustainable Development, Vol.10(4):5-13.

Lewis, J.I., 2013. Green innovation in China. China's wind power industry and the global transition to a low-carbon economy. Columbia University Press, New York.

Li, J., et al.., 2013. China Wind Power Outlook 2013, China Environmental Science Press, Beijing.

Mallett, Alexandra, Ockwell, David G, Pal, Prosanto, Kumar, Amit, Abbi, Y P, Haum, Ruediger, MacKerron, Gordon, Watson, Jim and Sethi, Girish, 2009. UK-India collaborative study on low carbon technology transfer: Phase II Final Report. Technical Report. Department of Energy and Climate Change, London.

Narain, A., Chaudhary, A., Krishna, C., 2014. Technological Trajectories for Climate Change Mitigation in Europe, China and India. Wind Energy in India. GDI Working Paper. GDI, Bonn.

Nordensvard, J. and Urban, F., 2015. The stuttering energy transition in Germany: Wind energy policy and feed-in tariff lock-in. Energy Policy, Vol. 82: 156-165.

Ockwell, D. and Mallett, A. (2013) Low carbon innovation and technology transfer, in Urban, F. and Nordensvard, J. (Eds.) (2013) Low carbon development: Key issues. Routledge, Abingdon

Ockwell, D. and Mallett, A. (eds.) (2012) Low Carbon Technology Transfer: From Rhetoric to Reality, Routledge, Abingdon

Ockwell, D., Mallett, A., Haum, R. and Watson, J. (2010) "Intellectual property rights and low carbon technology transfer: the two polarities of diffusion and development", Global Environmental Change, 20: 729-738

Ockwell, D., Watson, J., MacKerron, G., Pal, P., Yamin, F., Vasudevan, N., Mohanty, P., 2007. UK-India collaboration to identify the barriers to the transfer of low carbon energy technology. London, DEFRA.

Orth, M., 2008. The Power of the Wind - The Enercon Story, German Business Review, p. 11-12.

Ohmae, K., 1990. The Borderless World. Harper, New York. Orth 
Patel, P. (1995) "The Localised Production of Global Technology", Cambridge Journal of Economics, 19: 141-153.

Pietrobelli C. 2000. The Role of International Technology Transfer in the Industrialisation of Developing Countries. In Technology Transfer, eds. M. Elena and D. Schroeer. Aldershot, UK; Burlington.

Porter, M. E. (1990): The competitive advantage of nations, New York, Free Press.

Rogers, E. M., 2003. Diffusion of innovations. $5^{\text {th }}$ Edition. New York: Free Press.

Saviotti, P. (2005) On the co-evolution of technologies and institutions, in: M. Weber and J. Hemmelskamp (eds) Towards Environment Innovation Systems, pp. 9-31. Springer, Berlin.

Schmitz, H. and Lema, R., 2014. The Global Green Economy: Competition or Cooperation between Europe and China? Fagerberg, J, Laestadius, S. and Martin, B (eds), The Triple Challenge: Europe in a New Age. Oxford University Press, Oxford.

Urban, F., Bhasin, S., Chaudhary, A., Dai, Y., N., Lema, R., Ling, C. Narain, A., 2012. Technological trajectories for climate change mitigation in Europe, China and India. Phase 1: comparative analysis of policies and strategies for climate change mitigation. Final summary report. School of Oriental and African Studies, London.

Urban, F. and Nordensvärd, N., 2015. Nordensvard, J. and Urban, F., 2015. The stuttering energy transition in Germany: Wind energy policy and feed-in tariff lock-in. Energy Policy, Vol. 82: 156-165.

Urban, F., Nordensvärd, J., Zhou, Y., 2012. Key actors and their motives for wind energy innovation in China. Innovation and Development, Vol.2(1): 111-130.

Walz, R. and Delgado, J.N., 2012. Innovation in sustainability technologies in newly industrializing countries - results from a case study on wind energy, in: Innovation and Development, Vol. 2 (1):87-109.

Watson, J. (2008). Setting Priorities in Energy Innovation Policy: Lessons for the UK. ETIP Discussion Paper. Cambridge, MA, Belfer Center for Science and International Affairs, Kennedy School of Government, Harvard University.

Yin, R.K. (2009) Case Study Research: Design and Methods, California: SAGE Publications Zhou, Y., Li, X., Lema, R., Urban, F., 2015. Comparing the innovation strategies of Asian and European wind turbine firms through a patent lens. Science and Public Policy, in press. 